\title{
ANALISIS EFISIENSI PELAYANAN RAWAT INAP DITINJAU DARI INDIKATOR PELAYANAN RAWAT INAP PADA BLUD RSUD dr. H. SOEMARNO SOSROATMODJO KAPUAS TAHUN 2017
}

\author{
(Analysis The Efficiency Of Inpatient Services Of The Inpatients Services \\ Reviewed At Blud Rsud Dr. H. Soemarno \\ Sosroatmodjo Kapuas 2017)
}

\author{
Galih Persadha, Fakhrurrasyid Anshari, Aus Al Anhar \\ Program Studi Perekam Medis Dan informasi Kesehatan \\ Politeknik Unggulan Kalimantan \\ Email: gp1618@polanka.ac.id
}

\begin{abstract}
Activity that is routinely carried out al BLUD RSUD dr. H. Soemarno Sosroatmodjo Kapuas which calculate the efficiency of bed occupancy. Inpatient service indicators for the last 3 years have fluctuated but have not met the standards. The purpose of this research was to determine the efficiency of inpatient service based on indicators of inpatient service at BLUD RSUD dr. $H$. Soemarno Sosroatmodjo Kapuas in 2017. This type of research use descriptive quantitative cross sectional approach with observation method, namely observing and calculating directly in the field. Daily inpatient census from 00.00 to 24.00 at 08.00 is handed over to the medical record. In 2017 the BOR result 52,51\%, AvLOS 2,30 days, TOI 2,99 days, and BTO 58 times. Based on the measurement of Barber Johnson Chart the BOR value in the efficient area is the Cempaka room, while VIP, Isolation, ICU, VK, Teratai, Mawar, Perinatology, Kenanga, Dahlia, and Anggrek are outside the area efficiently. BOR values under the Health Department standards and Barber Johnson need to be made efforts to improve the quality of services including by completing facilities and infrastructure and improving service quality and human resource skills to restore public confidence in the hospital.
\end{abstract}

Keywords : Statistic, Indicators Of Inpatient Service, Barber Johnson Chart.

\section{ABSTRAK}

Aktivitas yang rutin dilakukan di BLUD RSUD dr. H. Soemarno Sosroatmodjo Kapuas yaitu menghitung tingkat efisensi hunian tempat tidur. Indikator pelayanan rawat inap 3 tahun terakhir terjadi fluktuasi akan tetapi belum memenuhi standar. Tujuan penelitian ini untuk mengetahui efisiensi pelayanan rawat inap berdasarkan indikator pelayanan rawat inap di BLUD RSUD dr. $\mathrm{H}$. Soemarno Sosroatmodjo Kapuas Tahun 2017. Jenis penelitian ini menggunakan deskriptif kuantitatif pendekatan cross sectional dengan metode observasi yaitu melakukan pengamatan langsung dilapangan. Sensus harian rawat inap terhitung dari pukul 00.00 sampai dengan pukul 24.00 pada pukul 08.00 diserahkan kebagian rekam medis. Tahun 2017 hasil BOR 52,51\%, AvLOS 2,30 hari, TOI 2,99 hari, dan BTO 58 kali. Berdasarkan pengukuran grafik Barber Johnson nilai BOR yang berada didaerah efisien yaitu ruang Cempaka, sedangkan VIP, Isolasi, ICU, VK, Teratai, Mawar, Perinatologi, Kenanga, Dahlia, dan Anggrek berada diluar daerah efisien. Nilai BOR dibawah standar Depkes dan Barber Johnson perlu dilakukan upaya peningkatan mutu pelayanan diantaranya dengan melengkapi sarana dan prasarana serta peningkatan kualitas pelayanan dan keterampilan sumber daya manusia untuk mengembalikan kepercayaan masyarakat kepada rumah sakit

Kata kunci : Statistik, Indikator Pelayanan Rawat Inap, Grafik Barber Johnson 


\section{PENDAHULUAN}

Menurut Peraturan Menteri Kesehatan Republik Indonesia No. 269/MENKES/PER/II/2008 Rekam Medis adalah berkas yang berisikan catatan dan dokumen tentang identitas pasien, pemeriksaan, pengobatan, tindakan, dan pelayanan lain yang telah diberikan kepada pasien. Data rekam medis diperoleh dari hasil pelayanan kesehatan yang diberikan kepada pasien dapat dimanfaatkan untuk bermacam-macam kegiatan di rumah sakit, salah satunya yaitu untuk data statistik kesehatan. Oleh karena itu rumah sakit sebagai institusi atau fasilitas pelayanan kesehatan harus mengumpulkan dan mengolah data secara efektif dan efisien dengan rekam medis yang lengkap. Pemanfaatan rekam medis dapat dipakai sebagai : pemeliharaan kesehatan dan pengobatan pasien, alat bukti dalam proses penegakkan hukum, disiplin kedokteran, dan kedokteran gigi dan penegakkan etika kedokteran dan etika kedokteran gigi, keperluan pendidikan dan penelitian, dasar pembayar biaya pelayanan kesehatan, dan data statistik kesehatan (Menkes RI, 2008).

Didalam proses pengambilan keputusan sebenarnya dilakukan transformasi dari data

Statistik rumah sakit menurut (Sudra, 2010) yaitu statistik yang menggunakan dan mengolah sumber data dari pelayanan kesehatan di rumah sakit untuk menghasilkan informasi, fakta dan pengetahuan berkaitan dengan pelayanan kesehatan di rumah sakit. Informasi dari statistik rumah sakit digunakan untuk perencanaan, memantau pendapatan dan pengeluaran dari pasien oleh pihak manajemen rumah sakit (Hatta, 2008).

Berdasarkan aspek ekonomi, tentu pihak manajemen menginginkan agar setiap tempat tidur (TT) yang telah disediakan selalu terisi dan digunakan oleh pasien. Jumlah TT yang kosong atau menganggur diharapkan sesedikit mungkin. Semakin lama seorang pasien menempati sebuah TT maka akan semakin banyak menghasilkan uang. Dari aspek medis terjadi arah penilaian yang bisa berlawanan. Tim medis akan lebih senang dan merasa berhasil kerjanya jika seorang pasien bisa segera sembuh sehingga tidak perlu lama dirawat, jadi tidak menggunakan TT terlalu lama (Sudra, 2010).

Indikator pelayanan rawat inap sudah diterapkan di BLUD RSUD dr. H. Soemarno Sosroatmodjo Kapuas yang bertujuan untuk mengukur pelayanan terhadap pasien dan tingkat efisiensi hunian tempat tidur (TT) khususnya rawat inap dengan menggunakan 4 parameter pengukuran yaitu Bed Occupancy Rate (BOR), Average Length Of Stay (AvLOS), Turn Over Interval (TOI), dan Bed Turn Over (BTO).

Berdasarkan hasil survei awal yang dilakukan dengan melihat data dari tahun 2014 sampai tahun 2016 maka didapatkan data sebagai berikut :

Tabel 1.1 Indikator Pelayanan Rawat Inap BLUD RSUD dr. H. Soemarno Sosroatmodjo Kapuas Tahun 2014-2016 Menurut Standar Depkes.

Tabel Indikator Pelayanan Rawat Inap BLUD

\begin{tabular}{ccccccc}
\hline No & Indikator & Standar Depkes & $\mathbf{2 0 1 4}$ & $\mathbf{2 0 1 5}$ & $\mathbf{2 0 1 6}$ & Efisiensi \\
\hline $\mathbf{1}$ & BOR & $60-85 \%$ & 49,06 & 57,20 & 52,33 & Belum \\
\hline $\mathbf{2}$ & AvLOS & $6-9$ Hari & 2,32 & 2,43 & 2,31 & Belum \\
\hline $\mathbf{3}$ & TOI & $1-3$ Hari & 3,39 & 2,57 & 3,02 & Efisien \\
\hline $\mathbf{4}$ & BTO & $40-60$ Kali & 55 & 61 & 58 & Efisien \\
\hline
\end{tabular}

Sumber : Bag. Pelaporan Rekam Medis BLUD RSUD dr. H. Sosroatmodjo Kapuas.

RSUD dr. H. Soemarno Sosroatmodjo Kapuas Tahun 2014-2016 Menurut Standar Barber Johnson. 


\begin{tabular}{lllllll} 
No & Indikator & Stdr BBJ & $\mathbf{2 0 1 4}$ & $\mathbf{2 0 1 5}$ & $\mathbf{2 0 1 6}$ & Efisien? \\
\hline $\mathbf{1}$ & BOR & 75-85\% & 49,1 & 57,2 & 52,3 & Belum \\
\hline $\mathbf{2}$ & AvLOS & 3-12 Hari & 2,32 & 2,43 & 2,31 & Belum \\
\hline $\mathbf{3}$ & TOI & 1-3 Hari & 3,39 & 2,57 & 3,02 & Efisien \\
\hline $\mathbf{4}$ & BTO & $>30$ Kali & 55 & 61 & 58 & Efisien \\
\hline
\end{tabular}

Sumber : Bag. Pelaporan Rekam Medis BLUD RSUD dr. H. Sosroatmodjo Kapuas.

Berdasarkan permasalahan nilai BOR dan AvLOS yang rendah maka peneliti ingin mengetahui penerapan indikator pelayanan rawat inap dan tertarik mengambil tema Karya Tulis IImiah "Analisis Efisiensi Pelayanan Rawat Inap Di Tinjau Dari Indikator Pelayanan Rawat Inap Pada BLUD RSUD dr. H. Soemarno Sosroatmodjo Kapuas Tahun 2017"

\section{METODE PENELITIAN}

Jenis penelitian yang digunakan dalam penelitian ini adalah jenis penelitian deskriptif kuantitatif yaitu bertujuan menjelaskan fenomena yang ada berdasarkan dengan angka-angka, guna menggambarkan tingkat efisiensi penggunaan tempat tidur setiap ruang keperawatan.

Metode yang dipakai dalam penetian ini adalah metode observasi, yaitu dengan melakukan pengamatan dan perhitungan secara langsung di lapangan dengan pendekatan cross sectional, yaitu dengan melihat dan mengumpulkan data yang sudah ada (Kurniawan, 2014).

Lokasi penelitian bertempat di BLUD RSUD dr. H. Soemarno Sosroatmodjo Kapuas di Jl. Tambun Bungai No. 16 Kapuas di Unit Rekam Medis BLUD RSUD dr. H. Soemarno Sosroatmodjo Kapuas yang dilaksanakan pada bulan April sampai dengan akhir penelitian pada bulan Agustus 2018.

Dalam penelitian ini variabel yang terdapat pada penelitian ini yaitu Bed Occupancy Rate (BOR), Average length Of Stay (AvLOS), Turn Over Interval (TOI), dan Bed Turn Over (BTO).

Bed Occupancy Rate (BOR) adalah persentase pemakaian tempat tidur pada satuan waktu tertentu. Nilai parameter BOR yang ideal menurut (Depkes RI, 2005) adalah antara 60-85\%

$$
\mathrm{BOR}=\frac{\text { Jumlah Hari Perawatan }(H P)}{\text { Jumlah TTxJumlah Hari Dalam Satu Periode }} \times 100 \%
$$

Average length Of Stay (AvLOS) adalah rata-rata lama rawat seorang pasien. Indikator ini memberikan gambaran mutu pelayanan. Nilai AvLOS yang ideal menurut (Depkes RI, 2005) antara 6-9 hari.

$$
\text { AvLOS }=\frac{\text { Jumlah Lama Dirawat }}{\text { Jumlah Pasien Keluar }(\text { Hidup }+ \text { Mati })}
$$

Turn Over Interval (TOI) adalah rata-rata hari dimana tempat tidur tidak ditempati, dari telah diisi ke saat terisi berikutnya. Nilai ideal TOI menurut (Depkes RI, 2005) pada kisaran 1-3 hari.

$$
\text { TOI }=\frac{(\text { Jumlah TTxPeriode })-\text { Hari Perawatan }}{\text { Jumlah Pasien Keluar }(\text { Hidup }+ \text { Mati })}
$$

Bed Turn Over (BTO) adalah frekuensi pemakaian tempat tidur pada satu periode, berapa kali tempat tidur dipakai dalam satu tahun waktu tertentu. Nilai ideal BTO menurut (Depkes RI, 2005) $40-50$ kali.

$$
\text { BTO }=\frac{\text { Jumlah Pasien Keluar }(\text { Hidup }+ \text { Mati })}{\text { Jumlah TT }}
$$




\section{HASIL DAN PEMBAHASAN Gambaran Umum}

Dalam sejarah perkembangannya Rumah Sakit Umum Kuala Kapuas pada awalnya berada di Kampung Barimba Kecamatan Kapuas Hilir dengan nama "Rumah Sakit Hangulan Sinta" yang didirikan oleh Zending Basle misionaris agam Kristen Protestan.

Selanjutnya pada tahun 1966 berpindah tempat ke JI. Piere Tendean hanya melayani rawat jalan, kemudian pada tahun 1969 baru melayani rawat inap dengan 48 tempat tidur dengan klasifikasi Rumah Sakit tipe D.

Kemudian pada tahun 1990 atas bantuan dana Loan Asian Developmant Bank dibangunlah Rumah Sakit Umum Daerah dr. H. Soemarno Sosroatmodjo Kuala Kapuas di atas tanah dengan ukuran $30.000 \mathrm{M} 2$ yang terletak di jalan Tambun Bungai No.16 seperti sekarang ini masih dengan klasifikasi tipe D. Masa inilah RSUD dr. H. Soemarno Sosroatmodjo diresmikan oleh Menteri Kesehatan RI pada tanggal 6 Februari 1993 dengan menempati gedung baru yang ada di Jl. Tambun Bungai No. 16 Kuala Kapuas.

\section{Jumlah Tempat Tidur}

Jumlah tempat tidur yang dimiliki oleh BLUD RSUD dr. H. Soemarno Sosroatmodjo Kapuas pada tahun 2017 adalah sebanyak 135 tempat tidur.

Tabel Rincian Jumlah Tempat Tidur BLUD RSUD dr. H. Soemarno Sosroatmodjo Kapuas Tahun 2017.

\begin{tabular}{|c|c|c|c|c|c|c|c|}
\hline No & RG/KLS & VIP & I & II & III & NKLS & JLH TT \\
\hline 1 & VIP/MLT & 9 & - & - & - & - & 9 \\
\hline 2 & ANGGREK & - & 8 & - & - & - & 8 \\
\hline 3 & DAHLIA & - & - & 4 & 12 & - & 16 \\
\hline 4 & KENANGA & - & 2 & 4 & 21 & - & 27 \\
\hline 5 & PERINATOLOGI & - & - & - & - & 14 & 14 \\
\hline 6 & MAWAR & - & 2 & 2 & 4 & - & 8 \\
\hline 7 & TERATAI & - & 2 & - & 15 & - & 17 \\
\hline 8 & ISOLASI & - & - & 6 & - & - & 6 \\
\hline 9 & CEMPAKA & - & - & 4 & 12 & - & 16 \\
\hline 10 & VK & - & 3 & - & - & 6 & 9 \\
\hline \multirow[t]{2}{*}{11} & ICU & - & - & - & - & 5 & 5 \\
\hline & JLH TT & 9 & 17 & 20 & 64 & 25 & 135 \\
\hline
\end{tabular}

Sumber : Indikator Pelayanan Badan Layanan Umum Daerah Rumah Sakit Umum Daerah dr. H. Soemarno Sosroatmodjo Kapuas Tahun 2017.

\section{Performance Rumah Sakit Tahun Terakhir}

Perkembangan BOR, AvLOS, TOI, BTO, GDR, dan NDR Tahun 2017

\begin{tabular}{lllll}
\hline No & Indikator & JLH Rata-Rata Hari & Ideal Depkes & Efisiensi \\
\hline $\mathbf{1}$ & BOR & $52,51 \%$ & $60-85 \%$ & Belum Efisien \\
\hline $\mathbf{2}$ & AvLOS & $2,30 \mathrm{Hari}$ & $6-9 \mathrm{Hari}$ & Belum Efisien \\
\hline $\mathbf{3}$ & TOI & $2,99 \mathrm{Hari}$ & $1-3 \mathrm{Hari}$ & Efisien \\
\hline $\mathbf{4}$ & BTO & $58 \mathrm{Kali}$ & $40-60 \mathrm{Kali}$ & Efisien \\
\hline $\mathbf{5}$ & GDR & $25,28 \mathrm{Permil}$ & $<45$ Permil & Efisien \\
\hline $\mathbf{6}$ & NDR & 10,47 Permil & $<25$ Permil & Efisien \\
\hline
\end{tabular}

Tabel Performance BLUD RSUD dr. H. Soemarno Sosroatmodjo Kapuas Tahun 2017 Sumber : Bag. Pelaporan BLUD RSUD dr. H. Soemarno Sosroatmodjo Kapuas. 
Berdasarkan data performance rumah sakit yang didapat bahwa parameter BOR dan AvLOS belum memenuhi standar Depkes.

BLUD RSUD dr. H. Soemarno Sosroatmodjo Kapuas melakukan pendataan pasien rawat inap dengan membuat Sensus Harian Rawat Inap yang dibuat oleh perawat masing-masing ruangan rawat inap terhitung dari pukul 00.00 ssampai dengan pukul 24.00 kemudian data tersebut diserahkan ke bagian rekam medis pada pagi hari berikutnya paling lambat pukul 08.00, SHRI digunakan untuk mengetahui Hari Perawatan (HP), Lama Dirawat (LD), Pasien Masuk, Pasien Keluar, Pasien Pindah Keruangan Lain, Pasien Yang Dipindahkan Dari Ruangan Lain, Pasien Meninggal, dan juga data sensus harian rawat inap sebagai bahan untuk membuat laporan indikator pelayanan rawat inap.

Hasil perhitungan BOR, AvLOS, TOI, dan BTO pada BLUD RSUD dr. H. Soemarno Sosroatmodjo Kapuas pada Tahun 2017 pada tabel 4.4.

Tabel Hasil Perhitungan Setiap Ruang/Kelas Periode Triwulan I Tahun 2017

\begin{tabular}{clllll}
\hline \multirow{2}{*}{ No } & \multirow{2}{*}{ RG/KLS } & \multicolumn{3}{c}{ Indikator } \\
\cline { 3 - 5 } & BOR & AvLOS & TOI & BTO \\
\hline 1 & VIP/MLT & 80,74 & 2,46 & 0,82 & 21 \\
\hline 2 & ANGGREK & 98,33 & 2,86 & 0,06 & 22,87 \\
\hline 3 & DAHLIA & 39,58 & 1,86 & 4,37 & 12,43 \\
\hline 4 & KENANGA & 51,32 & 2,79 & 3,60 & 12,19 \\
\hline 5 & PERINATOLOGI & 19,52 & 3,03 & 16,62 & 4,36 \\
\hline 6 & MAWAR & 44,86 & 3,09 & 5,03 & 9,88 \\
\hline 7 & TERATAI & 53,73 & 2,82 & 3,29 & 12,65 \\
\hline 8 & ISOLASI & 50,37 & 4,44 & 5,36 & 8,33 \\
\hline 9 & CEMPAKA & 76,04 & 1,53 & 0,80 & 27 \\
\hline 10 & VK & 38,77 & 1,71 & 4,28 & 12,89 \\
\hline 11 & ICU & 42,00 & 3,61 & 6,37 & 8,20 \\
\hline
\end{tabular}

Sumber : Hasil Perhitungan

Berdasarkan hasil perhitungan pada tabel 4.4 didapatkan perhitungan peruangan dalam Triwulan I dinyatakan bahwa nilai BOR yang tertinggi yaitu ruangan Anggrek $98,33 \%$, AvLOS yang tertinggi yaitu ruangan Isolasi 4,44 hari, TOl yang tertinggi yaitu ruangan Perinatologi 16,62 hari, dan BTO yang tertinggi yaitu ruangan Anggrek 22,87 kali.

Berdasarkan dari perhitungan yang dilakukan pada Triwulan II.

.Tabel Hasil Perhitungan Setiap Ruang/Kelas Periode Triwulan II Tahun 2017

\begin{tabular}{clllrl}
\hline \multirow{2}{*}{ No } & \multirow{2}{*}{ GG/KLS } & \multicolumn{3}{c}{ Indikator } \\
\cline { 3 - 6 } & BOR & AvLOS & TOI & BTO \\
\hline 1 & VIP/MLT & 61,54 & 2,60 & 2,25 & 15,56 \\
\hline 2 & ANGGREK & 91,07 & 2,83 & 0,38 & 21,63 \\
\hline 3 & DAHLIA & 49,59 & 2,13 & 3,18 & 14,44 \\
\hline 4 & KENANGA & 50,51 & 2,68 & 3,61 & 12,48 \\
\hline 5 & PERINATOLOGI & 32,42 & 3,44 & 9,26 & 6,64 \\
\hline 6 & MAWAR & 50 & 3,23 & 4,23 & 10,75 \\
\hline 7 & TERATAI & 46,54 & 2,89 & 4,47 & 10,88 \\
\hline 8 & ISOLASI & 34,25 & 4,05 & 9,70 & 6,17 \\
\hline 9 & CEMPAKA & 79,26 & 1,41 & 0,63 & 29,88 \\
\hline 10 & VK & 40,29 & 1,50 & 3,70 & 14,67 \\
\hline 11 & ICU & 24,18 & 1,75 & 8,63 & 8,00 \\
\hline & & Sumber : Hasil Perhitungan &
\end{tabular}


Berdasarkan hasil perhitungan pada tabel 4.5 didapatkan perhitungan berdasarkan Triwulan II dinyatakan bahwa nilai BOR yang tertinggi yaitu ruangan Anggrek 91,07\%, AvLOS yang tertinggi yaitu ruangan Isolasi 4,05 hari, TOI tertinggi yaitu ruangan Isolasi 9,70 hari, dan BTO yang tertinggi yaitu ruangan Cempaka 29,88 kali.

Berdasarkan dari perhitungan yang dilakukan pada Triwulan.

Tabel Hasil Perhitungan Setiap Ruang/Kelas Periode Triwulan III Tahun 2017

\begin{tabular}{|c|c|c|c|c|c|}
\hline \multirow{2}{*}{ No } & \multirow{2}{*}{ RG/KLS } & \multicolumn{4}{|c|}{ Indikator } \\
\hline & & BOR & AvLOS & TOI & BTO \\
\hline 1 & VIP/MLT & 54,95 & 2,42 & 2,80 & 14,78 \\
\hline 2 & ANGGREK & 103,40 & 2,64 & $-0,12$ & 26,13 \\
\hline 3 & DAHLIA & 156 & 2,27 & 2,10 & 17,13 \\
\hline 4 & KENANGA & 44,97 & 2,76 & 4,60 & 11 \\
\hline 5 & PERINATOLOGI & 29,19 & 4,18 & 13,61 & 4,79 \\
\hline 6 & MAWAR & 52,99 & 2,98 & 3,53 & 12,25 \\
\hline 7 & TERATAI & 50,13 & 2,70 & 3,68 & 12,47 \\
\hline 8 & ISOLASI & 43,48 & 3,8 & 6,24 & 8,33 \\
\hline 9 & CEMPAKA & 85,67 & 1,43 & 0,41 & 32,5 \\
\hline 10 & VK & 46,86 & 1,60 & 2,95 & 16,56 \\
\hline 11 & ICU & 15,87 & 1,43 & 12,90 & 6,00 \\
\hline
\end{tabular}

Sumber : Hasil Perhitungan

Berdasarkan hasil perhitungan pada tabel 4.6 didapatkan perhitungan berdasarkan Triwulan III dinyatakan bahwa BOR yang tertinggi yaitu ruangan Dahlia 156\%, AvLOS yang tertinggi yaitu ruangan Isolasi 3,8 hari, TOI yang tertinggi yaitu ruangan Perinatologi 13,61 hari, dan BTO yang tertinggi yaitu ruangan Anggrek 26,13 kali.

Berdasarkan dari perhitungan yang dilakukan pada Triwulan.

Tabel Hasil Perhitungan Setiap Ruang/Kelas Periode Triwulan IV Tahun 2017

\begin{tabular}{|c|c|c|c|c|c|}
\hline \multirow{2}{*}{ No } & \multirow{2}{*}{ RG/KLS } & \multicolumn{4}{|c|}{ Indikator } \\
\hline & & BOR & AvLOS & TOI & BTO \\
\hline 1 & VIP/MLT & 52,78 & 2,55 & 3,18 & 13,67 \\
\hline 2 & ANGGREK & 111,82 & 2,71 & $-0,39$ & 27,75 \\
\hline 3 & DAHLIA & 54,28 & 2,47 & 2,93 & 14,38 \\
\hline 4 & KENANGA & 46,50 & 2,80 & 4,37 & 11,26 \\
\hline 5 & PERINATOLOGI & 22,20 & 2,76 & 13,18 & 5,43 \\
\hline 6 & MAWAR & 51,77 & 3,01 & 3,74 & 11,88 \\
\hline 7 & TERATAI & 35,42 & 2,62 & 6,60 & 9 \\
\hline 8 & ISOLASI & 47,83 & 3,47 & 4,88 & 9,83 \\
\hline 9 & CEMPAKA & 73,64 & 1,38 & 0,85 & 28,5 \\
\hline 10 & VK & 54,35 & 1,31 & 1,94 & 21,67 \\
\hline 11 & ICU & 10,87 & 1,00 & 16,40 & 5,00 \\
\hline
\end{tabular}

Sumber : Hasil Perhitungan

Berdasarkan hasil perhitungan pada tabel 4.7 didapatkan perhitungan berdasarkan Triwulan IV dinyatakan bahwa nilai BOR yang tertinggi yaitu ruangan Anggrek $111,82 \%$, AvLOS yang tertinggi yaitu ruangan Isolasi 3,47 hari, TOI yang tertinggi yaitu ruangan ICU 16,40 hari, dan BTO yang tertinggi yaitu ruangan Cempaka 28,5 kali.

Perbedaan hasil perhitungan berdasarkan periode Semester dari setiap ruang perawatan terhitung dari Semester I, dan II, guna mengetahui peningkatan efisiensi dari setiap ruangan per enam bulan. Berdasarkan dari perhitungan yang dilakukan pada Semester I. 
Tabel Hasil Perhitungan Setiap Ruang/Kelas Periode Semester I Tahun 2017

\begin{tabular}{clllll}
\hline \multirow{2}{*}{ No } & \multirow{2}{*}{ RG/KLS } & \multicolumn{4}{c}{ Indikator } \\
\cline { 3 - 5 } & VIP/MLT & 71,09 & 2,52 & 1,43 & 36,56 \\
\hline 1 & ANGGREK & 94,68 & 2,85 & 0,22 & 44,50 \\
\hline 2 & DAHLIA & 44,61 & 2 & 3,73 & 26,88 \\
\hline 3 & KENANGA & 50,91 & 2,74 & 3,60 & 24,67 \\
\hline 4 & PERINATOLOGI & 26,01 & 3,28 & 12,18 & 11 \\
\hline 5 & MAWAR & 47,44 & 3,16 & 4,61 & 20,63 \\
\hline 6 & TERATAI & 50,11 & 2,86 & 3,84 & 23,53 \\
\hline 7 & ISOLASI & 42,27 & 4,28 & 7,21 & 14,5 \\
\hline 8 & CEMPAKA & 77,66 & 1,47 & 0,71 & 56,88 \\
\hline 9 & VK & 39,53 & 1,60 & 3,97 & 27,56 \\
\hline 10 & ICU & 33,04 & 2,69 & 7,48 & 16,20 \\
\hline 11 & & & &
\end{tabular}

Sumber : Hasil Perhitungan

Berdasarkan hasil perhitungan pada tabel 4.8 didapatkan perhitungan berdasarkan Semester I dinyatakan bahwa nilai BOR yang tertinggi yaitu ruangan Anggrek 94,68\%, AvLOS yang tertinggi yaitu ruangan Isolasi 4,28 hari, TOI tertinggi yaitu ruangan Perinatologi 12,18 hari, dan BTO yang tertinggi yaitu Cempaka 56,88 kali.

Berdasarkan dari perhitungan yang dilakukan pada Semester.

Tabel Hasil Perhitungan Setiap Ruang/Kelas Periode Semester II Tahun 2017

\begin{tabular}{|c|c|c|c|c|c|}
\hline \multirow{2}{*}{ No } & \multirow{2}{*}{ RG/KLS } & \multicolumn{4}{|c|}{ Indikator } \\
\hline & & BOR & AvLOS & TOI & BTO \\
\hline 1 & VIP/MLT & 53,86 & 2,48 & 2,98 & 28,44 \\
\hline 2 & ANGGREK & 107,61 & 2,68 & $-0,26$ & 53,88 \\
\hline 3 & DAHLIA & 57,61 & 2,37 & 0,11 & 31,50 \\
\hline 4 & KENANGA & 45,73 & 2,78 & 4,49 & 22,26 \\
\hline 5 & PERINATOLOGI & 25,70 & 2,42 & 11,13 & 12,29 \\
\hline 6 & MAWAR & 52,38 & 2,99 & 3,63 & 24,13 \\
\hline 7 & TERATAI & 42,77 & 2,67 & 4,90 & 21,47 \\
\hline 8 & ISOLASI & 45,65 & 3,62 & 5,50 & 18,17 \\
\hline 9 & CEMPAKA & 79,65 & 1,40 & 0,61 & 61 \\
\hline 10 & VK & 50,60 & 1,44 & 2,38 & 38,22 \\
\hline 11 & ICU & 13,37 & 1,24 & 14,49 & 11,00 \\
\hline
\end{tabular}

Sumber : Hasil Perhitungan

Berdasarkan hasil perhitungan pada didapatkan perhitungan berdasarkan Semester II dinyatakan bahwa nilai BOR yang tertinggi yaitu ruangan Anggrek 107,61\%, AvLOS yang tertinggi yaitu ruangan Isolasi 3,62 hari, TOI yang tertinggi yaitu ruangan ICU 14,49 hari, dan BTO yang tertinggi yaitu ruangan Anggrek 53,88 kali.

Perbedaan hasil perhitungan berdasarkan periode Tahunan dari setiap ruang perawatan terhitung dari satu tahun guna mengetahui peningkatan efisiensi dari setiap ruangan satu tahun 2017. Berdasarkan dari perhitungan yang dilakukan pada satu.

Tabel Hasil Perhitungan Setiap Ruang/Kelas Periode Satu Tahun 2017

\begin{tabular}{clllll}
\hline \multirow{2}{*}{ No } & \multirow{2}{*}{ RG/KLS } & \multicolumn{3}{c}{ Indikator } \\
\cline { 3 - 6 } & & BOR & AvLOS & TOI & BTO \\
\hline 1 & VIP/MLT & 62,40 & 2,50 & 2,11 & 65,00 \\
\hline 2 & ANGGREK & 101,20 & 2,75 & $-0,04$ & 98,38 \\
\hline 3 & DAHLIA & 51,16 & 2,20 & 3,05 & 58,38 \\
\hline 4 & KENANGA & 48,30 & 2,76 & 4,02 & 46,93 \\
\hline 5 & PERINATOLOGI & 25,85 & 3,05 & 11,62 & 23,29 \\
\hline
\end{tabular}


Volume 1 No. 1 (April, 2019)

\begin{tabular}{clllll}
\hline 6 & MAWAR & 49,93 & 3,07 & 4,08 & 44,75 \\
\hline 7 & TERATAI & 46,41 & 2,76 & 4,35 & 45,00 \\
\hline 8 & ISOLASI & 43,97 & 3,91 & 6,26 & 32,67 \\
\hline 9 & CEMPAKA & 78,66 & 1,44 & 0,66 & 117,88 \\
\hline 10 & VK & 45,11 & 1,50 & 3,05 & 65,78 \\
\hline 11 & ICU & 23,12 & 2,10 & 10,32 & 27,20 \\
\hline & & Sumber : Hasil Perhitungan & &
\end{tabular}

Berdasarkan hasil perhitungan pada didapatkan perhitungan dalam periode satu tahun 2017 guna melihat perbandingan antara ruang perawatan, dinyatakan bahwa nilai BOR yang tertinggi yaitu ruangan Anggrek 101,20\%, AvLOS yang tertinggi yaitu ruangan Mawar 3,07 hari, TOI yang tertinggi yaitu ruangan Perinatologi 11,62 hari, dan BTO yang tertinggi yaitu ruangan Cempaka 117,88 kali.

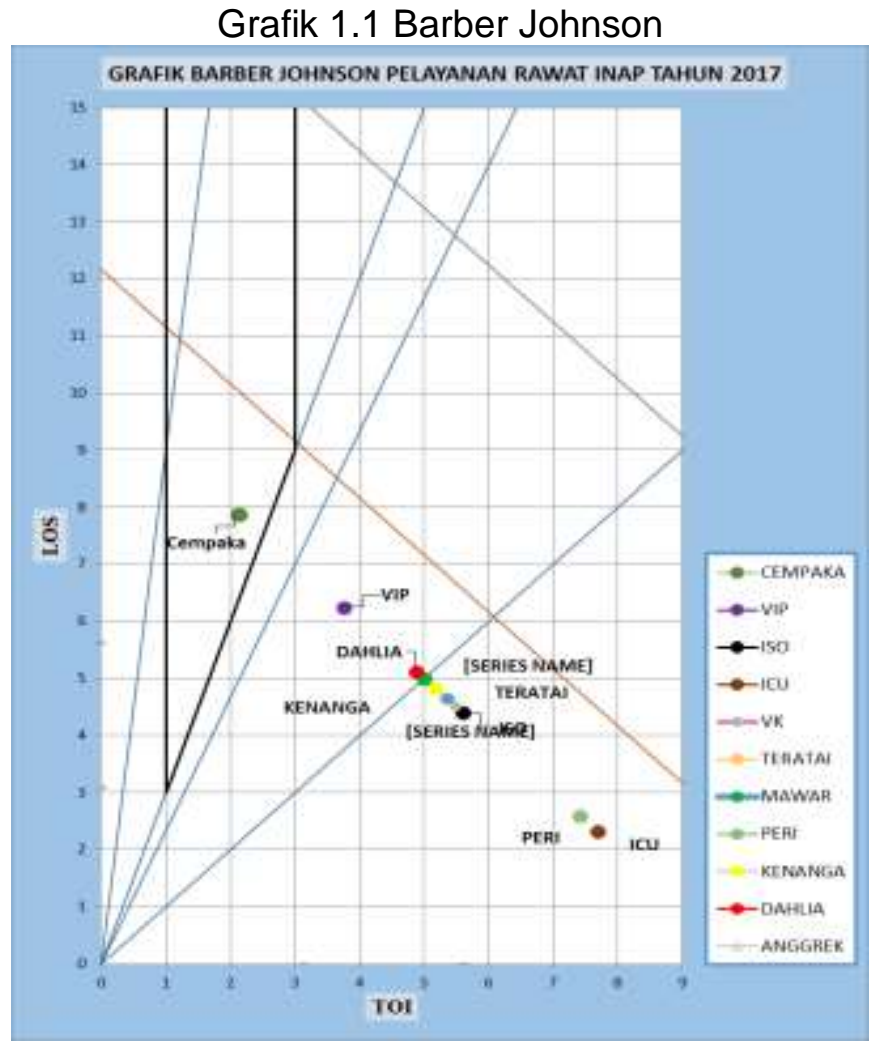

Berdasarkan pada grafik 1.1 bahwa titik BOR yang masuk didaerah efisien yaitu Ruangan Cempaka, titik BOR Ruang VIP/MLT berada diluar daerah efisien, titik BOR Ruangan Isolasi berada diluar daerah, titik BOR Ruangan ICU berada diluar daerah efisien, titik BOR Ruangan VK berada diluar daerah efisien, titik BOR Ruang Teratai berada diluar daerah efisien. titik BOR Ruangan Mawar berada diluar daerah efisien, titik BOR Ruangan Perinatologi berada diluar daerah efisien, titik BOR Ruangan Kenanga berada diluar daerah efisien, titik BOR Ruangan Dahlia berada diluar daerah efisien, dan titik BOR Ruangan. Anggrek berada diluar daerah efisien/melebihi dari daerah efisien.

\section{Pembahasan}

Sensus Harian Rawat Inap (SHRI) dilakukan setiap harinya mulai pukul 00.00 sampai dengan pukul 24.00 kemudian data tersebut diserahkan ke bagian rekam medis pada pagi hari berikutnya paling lambat pukul 08.00, data sensus harian rawat inap digunakan sebagai data dasar dalam penghitungan efisiensi pelayanan rawat inap. 
Menurut (Sudra, 2010) sensus harian rawat inap tidak hanya menghitung jumlah pasien yang dirawat akan tetapi juga melihat jumlah pasien awal, pasien baru masuk, pasien transfer, dan pasien keluar atau bangsal hidup maupun mati.

Berdasarkan hasil pengukuran yang dilakukan pada grafik 1.1 maka didapatkan hasil titik BOR pada Ruangan Cempaka berada didalam daerah efisien dengan BOR 78,66\%, sedangkan untuk Ruangan VIP/MLT BOR 62,40\%, Ruangan Isolasi BOR 43,90\%, Ruangan ICU BOR 23,12\%, Ruangan VK BOR 45,11\%, Ruangan Teratai BOR 46,41\%, Ruangan Mawar BOR 49,93\%, Ruangan Perinatologi BOR 25,85\%, Ruangan Kenanga BOR 48,30\%, Ruangan Dahlia BOR $51,16 \%$ berada diluar daerah efisien, pada Ruangan Anggrek BOR 101,20\% melebihi dari standar ideal BOR Depkes maupun ideal BOR Barber Johnson, pada Ruangan Cempaka sudah memenuhi dari standar Depkes yaitu 60\%-85\% maupun standar Barber Johnson yaitu 75\%-85\%.

Berdasarkan nilai ideal BOR secara statistik semakin tinggi nilai BOR berarti semakin tinggi juga penggunaan tempat tidur untuk perawatan pasien, namun dari segi aspek medis semakin banyak pasien yang dilayani semakin sibuk dan berat pula beban kerja kepada petugas kesehatan yang berada diruangan tersebut yang berakibat pasien kurang mendapat perhatian dan kemungkinan bisa menimbulkan dampak infeksi nosokomial juga meningkat.

Di sisi lain, jika nilai BOR rendah maka penggunaan tempat tidur yang tersedia juga rendah dari yang telah disediakan. Dengan kata lain, jumlah pasien yang sedikit bisa berakibat sulitnya pendapatan ekonomi bagi rumah sakit. dalam menyikapi hal tersebut perlu adanya nilai yang ideal bisa menyeimbangkan antara aspek medis dan aspek ekonomi.

Berdasarkan pada grafik 1.1didapatkan bahwa titik BOR Ruangan Cempaka berada dalam daerah efisien dengan BOR 78,66\% yang berarti sudah memenuhi dari standar Barber Johnson. Sedangan untuk Ruangan VIP/MLT, Anggrek, Dahlia, Kenanga, Perinatologi, Mawar, Teratai, Isolasi, Cempaka, VK, dan ICU belum sesuai atau belum berada dalam daerah efisien.

Berdasarkan analisa yang dilakukan pada grafik 1.1diketahui bahwa hasil pelayanan rawat inap pada Ruangan Cempaka sudah efisien akan tetapi untuk ruangan yang lain masih berada diluar daerah efisien. Pada Ruangan Anggrek posisi BOR ada diluar daerah efisien yaitu pada angka $101,20 \%$ hal tersebut terjadi kemungkinan diakibatkan karena adanya perubahan perilaku masyarakat dalam pemenuhan kebutuhan kesehatan melalui mekanisme BPJS PBI dan Non-PBI sehingga tempat tidur yang tersedia tidak memenuhi kebutuhan pasien, untuk ruangan yang lain nilai BOR masih dibawah standar.

\section{KESIMPULAN}

Sensus Harian Rawat Inap (SHRI) dilakukan setiap harinya mulai pukul 00.00 sampai dengan pukul 24.00 kemudian data tersebut diserahkan ke bagian rekam medis pada pagi hari berikutnya paling lambat pukul 08.00, data sensus harian rawat inap digunakan sebagai data dasar dalam penghitungan efisiensi pelayanan rawat inap.

Berdasarkan hasil perhitungan periode satu tahun 2017 didapatkan hasil BOR sebesar 52,51\%, AvLOS sebesar 2,30 hari, TOI sebesar sebesar 2,99 hari, dan BTO sebesar 58 kali.

Triwulan I nilai BOR tertinggi yaitu Ruangan Anggrek 98,33\%, AvLOS tertinggi yaitu Ruangan Isolasi 4,44 hari, TOI tertinggi yaitu Ruangan Perinatologi 16,62 hari, dan BTO tertinggi yaitu Ruangan Anggrek 22,87 kali.

Triwulan II dinyatakan bahwa nilai BOR tertinggi yaitu Ruangan Anggrek 91,07\%, AvLOS tertinggi yaitu Ruangan Isolasi 4,05 hari, TOI tertinggi yaitu Ruangan Isolasi 9,70 hari, dan BTO tertinggi yaitu Ruangan Cempaka 29,88 kali.

Triwulan III dinyatakan bahwa BOR tertinggi yaitu Ruangan Dahlia 156\%, AvLOS tertinggi yaitu Ruangan Isolasi 3,8 hari, TOI tertinggi yaitu Ruangan Perinatologi 13,61 hari, dan BTO tertinggi yaitu Ruangan Anggrek 26,13 kali.

Triwulan IV dinyatakan bahwa nilai BOR tertinggi yaitu Ruangan Anggrek 111,82\%, AvLOS tertinggi yaitu Ruangan Isolasi 3,47 hari, TOI tertinggi yaitu Ruangan ICU 16,40 hari, dan BTO tertinggi yaitu Ruangan Cempaka 28,5 kali.

Semester I dinyatakan bahwa nilai BOR tertinggi yaitu Ruangan Anggrek 94,68\%, AvLOS tertinggi yaitu Ruangan Isolasi 4,28 hari, TOI tertinggi yaitu Ruangan Perinatologi 12,18 hari, dan BTO tertinggi yaitu Ruangan Cempaka 56,88 kali. 
Semester II dinyatakan bahwa nilai BOR yang tertinggi yaitu Ruangan Anggrek 107,61\%, AvLOS tertinggi yaitu Ruangan Isolasi 3,62 hari, TOI tertinggi yaitu Ruangan ICU 14,49 hari, dan BTO tertinggi yaitu Ruangan Anggrek 53,88 kali.

Berdasarkan Grafik Barber Johnson bahwa titik BOR terdapat satu ruang berada dalam daerah efisien yaitu Ruang Cempaka dan satu ruangan yang berada diluar daerah efisien dengan nilai BOR melebihi standar barber johnson yaitu ruangan Anggrek, sedangkan untuk ruang yang lain nilai BOR berada diluar daerah efisien dan lebih kecil dari standar Barber Johnson diantaranya adalah Ruangan VIP/MLT, Kenanga, Dahlia, Perinatologi, Mawar, Teratai, Isolasi, VK, ICU

\section{DAFTAR PUSTAKA}

Depkes RI. (2005). Petunjuk Pengisian, Pengolahan, dan Penyajian Data Rumah Sakit. Jakarta.

Dharmawan, Y. (2006). Sistem Informasi Efisiensi Penggunaan Tempat Tidur Unit Rawat Inap Dengan Menggunakan Indikator Grafik Barber Johnson Di Rumah Sakit Panti Wilasa Citarum Semarang, 16.

Hatta. (2008). Pedoman Manajemen Informasi Kesehatan di Sarana Pelayanan Kesehatan. Jakarta: Universitas Indonesia (UI-Press).

Menkes RI. (2008). Peraturan Menteri Kesehatan RI No. 269 Tentang Rekam Medis. Jakarta.

Sudra, R. I. (2010). Statistik Rumah Sakit. Yogyakarta: Graha Ilmu. 